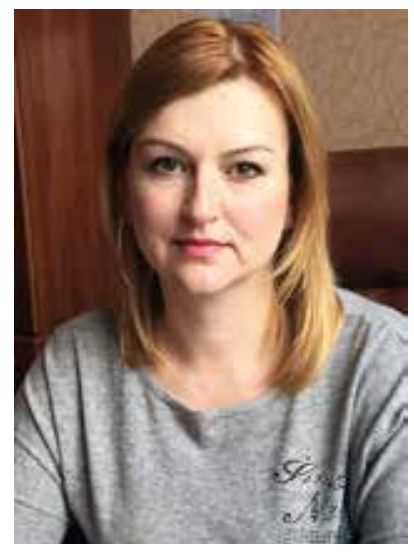

\title{
Юлія Меркулова,
}

каньидат юричичних наук,

Аоцент кафредри криміналістики та психології

ОАеського Аержавного університету внутрішніх справ

ORCID: 0000-0002-7691-842X

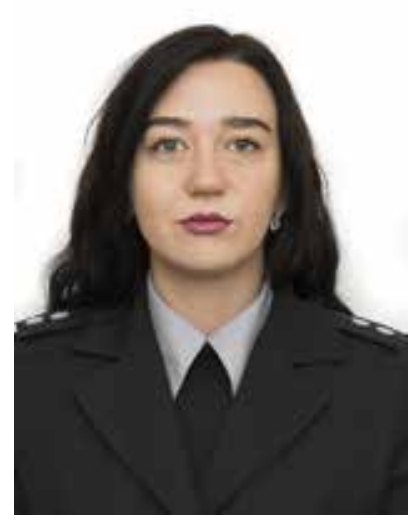

\section{Марина Ааніч,} слухач магістратури

ОАеського Аержавного університету внутрішніх справ ORCID: 0000-0003-2939-9951

https://doi.org/10.32782/2306-9082/2020-40-13

УдК 343.54:340.0

\section{Колізії в українському законодавстві щодо злочинів, скоєних проти статевої свободи та статевої недоторканності малолітньої особи}

Для правоохоронних органів і громадськості сексуальне насилля, особливо щодо дітей, є однією з основних соціальних проблем. Батьки, розуміючи існування цієї проблеми та її стан у суспільстві, відчувають тривогу за своїх дітей. Законодавчі органи, поліція та служби захисту дітей працюють над тим, щоб зменшити кількість цих злочинів. На початку 2020 року в управлінні захисту прав дітей та протидії насильству створили відділ протидії насильству щодо дітей. Незважаючи на це, проблема залишається. Емпіричні дані про ці злочини майже відсутні.

Нашу увагу привернули питання, пов'язані з вибором методів примусового впливу на осіб, які скоїли злочини сексуального характеру щодо неповнолітніх: що варто використовувати примусові заходи медичного характеру 
(лікування сексуального інтересу) або заходи, пов'язані з настанням кримінальної відповідальності за вчинене діяння?

Актуальність дослідження полягає в тому, що за статистикою кримінальних правопорушень за 2019 рік зареєстровано понад 550 злочинів проти статевої свободи та недоторканності дітей. Протягом 2019 року виявилося вдвічі більше потерпілих від згвалтування порівняно з 2018 роком [1]. Ще однією серйозною проблемою є те, що майже немає жодної інформації про справжню поширеність цієї девіації. Також практично немає статистики про людей із розладом сексуальної переваги у формі педофілії, які ніколи не скоювали злочини проти дітей, хоча існування такої категорії, на думку багатьох авторів, не викликає сумнівів.

Дослідження основних аспектів проблематики знайшло відображення в наукових працях вітчизняних і зарубіжних учених: Д.Р. Ворлінг, О.О. Дудоров, Т. Бугаєць, Н.В. Дворянчиков, Н.Г. Вартанян, К.Д. Янішевська, І.В. Левенець та інші. Однак питання стосовно настання кримінальної відповідальності за вчинення сексуального насильства над дітьми та його місце в системі покарання досі залишається відкритим.

Метою статті є дослідження педофілії як суспільно небезпечного явища та визначення його місця в системі покарання щодо настання кримінальної відповідальності за вчинене діяння.

Педофілія - сексуальний потяг до дітей і підлітків; нерідко трапляється в судово-психіатричній практиці через притягнення до кримінальної відповідальності за розбещення неповнолітніх. Педофілія, як і содомія (скотолозтво) та некрофілія (статеві акти з трупами), у багатьох випадках є симптомом статевої слабкості, яка призводить до пошуків збуджуючих моментів. В однієї і тієї ж особи можливе поєднання різних форм статевих збочень [2].
Педофілія, будучи порушенням сексуальної орієнтації, може виражатись у різноманітних формах - від звичайних фантазій до жорстоких убивств, від обнімань до пестощів, мастурбації, анального або генітального контакту тощо. Педофіл може виправдовувати свої дії їхньою «освітньою» суттю, сексуальним задоволенням, що отримує дитина, або ж сексуальною провокацією з боку дитини. Фахівці наголошують також на притаманній педофілії тривалості сексуальних фантазій або фактичних посягань на дітей [3].

Згідно з МКХ-10 (Міжнародна класифікація хвороб), педофілія як хвороба визначена під номером F65.4. Ця класифікація дає поняття педофілії, як сексуального потягу до дітей (хлопчиків, дівчаток або до тих i інших) зазвичай передпубертатного або раннього пубертатного періоду розвитку особистості. До того ж наявні певні ознаки, які вирізняють цю хворобу з-поміж інших. По-перше, особі, яка страждає на це захворювання, властиве інтенсивне бажання статевих актів із дитиною або аналогічні сексуальні фантазії, які виникають періодично. По-друге, такі особи діють відповідно до цих уподобань, а в разі неможливості задоволення зазначених бажань відчувають серйозний стрес. По-третє, наведені симптоми спостерігаються в них протягом щонайменше шести місяців [4].

Згідно з класифікацією F65.4 педофіл постійно чи більшість часу відчуває статевий потяг до дітей або до осіб пубертатного віку. Індивідуум із таким діагнозом має бути не молодшим за 16 років і він щонайменше на 5 років повинен бути старшим за об'єкт тяжіння, а останньому має бути не більше ніж 13 років. Проблема педофілії виявляється у відхиленні, яке проявляється у прагненні вчинювати дії сексуального характеру з дітьми [5]. Якщо звернутися до Кримінально-виконавчого кодексу України 
(далі - КВК), а саме до статті 6, ми визначимо, що будь-яка міра покарання передбачає виправлення та ресоціалізацію засудженого. Виправлення засудженого - процес позитивних змін, які відбуваються в його особистості та створюють у нього готовність до самокерованої правослухняної поведінки.

Ресоціалізація - свідоме відновлення засудженого в соціальному статусі повноправного члена суспільства; повернення його до самостійного загальноприйнятого соціально-нормативного життя в суспільстві [6].

За Кримінальним кодексом України (далі - ККУ) можна виділити такі статті, які регулюють злочини, скоєні педофілами: згвалтування (ст. 152), сексуальне насильство (ст. 153), статеві зносини з особою, яка не досягла шістнадцятирічного віку (ст. 155) та розбещення неповнолітніх (156) [7].

Треба зазначити, що після посилення санкції статей 152 та 153 ККУ, відповідальність за злочини, скоєні щодо особи, яка не досягла чотирнадцяти років без добровільної її згоди, та часткового ухвалення законопроєкту № 0887, який набрав чинності 16 січня 2020 року, дає надію на те, що процес удосконалення законодавства в цьому питанні матиме подальший розвиток.

Але санкції перших частин статей 155, 156 визначають тільки покарання у вигляді обмеження волі на строк до п'яти років або позбавлення волі на той самий строк, а в разі здійснення це членами сім'ї або близькими родичами - караються позбавленням волі на строк від п'яти до восьми років із позбавленням права обіймати певні посади чи займатися певною діяльністю на строк до трьох років або без такого. Тобто міра покарання, визначена в ККУ, не відповідає цілям та завданням, зазначеним у КВК. Цей вид покарання не може вплинути на психічний стан особи, адже ця хвороба вважається невиліковною. На нашу думку, законодавцям треба звернути увагу на цю проблему. Потрібно або посилити строки покарання в статтях 155 та 156 ККУ з подальшим лікуванням у психіатричному закладі або здійснити госпіталізацію до психіатричного закладу зі звичайним наглядом.

Звичайно, не кожна особа, яка підозрюється чи обвинувачується за цими статтями ККУ, повинна мати розлади сексуального збочення у вигляді педофілії, це може вчинити й особа, яка не має цієї хвороби. Для цього необхідне проведення судово-медичної й судово-психіатричної експертизи, які доведуть брак протипоказань і наявність або брак відповідного діагнозу. Проте якщо виділяти категорію педофілів окремо від інших правопорушників, то відповідно до ККУ та КВК наше законодавство не має чітко визначеної структури виправлення та ресоціалізації цієї категорії злочинців та психічно хворих одночасно.

Наприклад, свого часу в Бельгії педофіл М. Дютру здійснив насильство і вбивство п'ятьох дітей. У 1985 році він був засуджений до позбавлення волі на 12 років, але через шість років «за зразкову поведінку» бельгійський міністр юстиції достроково звільнив його з місць позбавлення волі. Перебуваючи на волі, М. Дютру повторно вчинив аналогічні вбивства. Коли його судили, бельгійці вимагали смертної кари педофілам [8].

Ще 21 червня 2017 року до Верховної Ради України було надано законопроєкт № 0887 про внесення змін до деяких законів України (щодо впровадження Єдиного реєстру осіб засуджених за злочини проти статевої свободи та статевої недоторканності малолітньої чи малолітнього та посилення відповідальності за злочини, скоєні проти статевої свободи та статевої недоторканності малолітньої чи малолітнього) [9].

Доопрацьований проєкт № 0887, успадкований депутатами від парламенту попереднього скликання (під 
час роботи якого він був зареєстрований під № 6607), є результатом дворічної дискусії між законодавцями та експертами. Серед іншого він передбачав добровільну хімічну кастрацію злочинців із педофілією та засуджених відповідно до статей Кримінального кодексу, а також «напівзакритий» реєстр засуджених за злочини проти статевої свободи неповнолітніх. Однак Україна не була готова до запровадження добровільної хімічної кастрації. Справді, одним із головних аргументів відмови від хімічної кастрації $\mathrm{e}$ корупційний складник і не досконала система вітчизняного законодавства.

Яскравим прикладом $є$ історія Сергія Ткача, який протягом 25 років гвалтував і вбивав дітей. Дев'ятьох чоловіків помилково підозрювали у злочинах, які він скоїв. Троє з них були засуджені, i, як результат, один покінчив життя самогубством у СІЗО ще до вироку суду [1].

Якщо ми звернемо увагу на запровадження єдиного реєстру осіб, засуджених за злочини проти сексуальної свободи та статевої недоторканності неповнолітніх, та посилення відповідальності за злочини, скоєні проти сексуальної свободи та сексуальної цілісності, можна зробити висновки про те, що це справді новаторський підхід до розв'язання цієї проблеми в Україні, тоді як для європейських країн це вже давно пройдений шлях. Цей реєстр було вирішено розробити напівзакритим задля усунення провокування самосуду з боку населення. Окрім прокуратури, слідчих та інших уповноважених органів Національної поліції України й Державного бюро розслідувань, реєстром можуть користуватися керівники закладів, у яких робота ведеться переважно 3 дітьми, малолітніми та неповнолітніми дітьми аби під час прийняття на роботу є можливість перевірити особу, чи є вона в цьому реєстрі. Проте станом на 2020 рік цей реєстр ще не розроблений і не ввійшов у дію.
Насправді, окрім проблеми розв’язання питання педофілії на законодавчому рівні, величезною проблемою залишається емоційний та психічний стан дітей, які зазнали цього виду насилля. Науковці вважають, що особи, які в дитинстві зазнали жорстокого ставлення та сексуального насильства, підсвідомо прагнуть відтворити такий життєвий досвід у дорослому житті, оскільки не знають іншої моделі поведінки. Наслідками насильства є схильність до наслідування, тобто адитивної, девіантної, делінквентної та асоціальної поведінки [9].

Опитування дітей, проведене в межах «Комплексної оцінки масштабів продажу дітей, дитячої проституції та порнографії в Україні», дало змогу встановити, що у віковій групі 14-18 років отримували пропозицію: оголитися повністю або частково 18,8 \% (погодилися - 11 \%), дозволити доторкнутися до оголених частин тіла - 15,9 \% (погодилися $-10,4 \%)$, вступити в статевий акт за гроші, речі або послуги - 14,5\% (погодилися - 7,8 \%), сфотографуватися або знятися у фільмі в оголеному вигляді - $6,7 \%$ (погодилися - 3,2 \%), учинити інші дії інтимного характеру - 7,2 \% (погодилися - 3,6 \%). Якщо йдеться про дітей віком 6-13 років, то серед них отримували пропозицію показати оголене тіло або його частину 10,5 \% (погодилися - 3,9 \%), дозволити доторкнутися до оголених частин тіла - 7,5\% (погодилися $-2,8 \%$ ), вступити в статевий акт за гроші, речі або послуги $5,2 \%$ (погодилися - 1,6 \%), сфотографуватися або знятися на відео в оголеному вигляді - 2,1 \% (погодилися $-0,8 \%$ ), учинити інші дії інтимного характеру - 1,9 \% (погодилися $-0,5 \%$ ) [10].

Жертвами сексуального насильства втричі частіше стають саме дівчатка, але що стосується хлопчиків, то сексуальне насильство в їхній 
бік характеризується більш важким і збоченим способом впливу. Сексуальне зловживання щодо хлопчиків породжує більше проблем, пов'язаних із сексуальною ідентифікацією, ніж у дівчаток.

Психологами визначено, що, на відміну від дорослих, дитина, яка стала жертвою сексуального насильства, завжди перебуває в критичній фазі свого розвитку. Тому, досліджуючи психологічні наслідки насильства, які пережила дитина, вкрай важливо враховувати розвиток її психіки у відповідному віковому періоді, оскільки реакція психіки на певну травматичну ситуацію може бути різною.

Найбільш загальними реакціями з урахуванням вікових особливостей можна позначити такі [11]:

1. Діти до трьох років - страх перед чужими людьми, сплутаність почуттів, порушення сну, втрата апетиту, агресія, страх, застосування під час гри елементів сексуальних маніпуляцій.

2. Дошкільнята - сплутаність почуттів, почуття провини, відрази і сорому, почуття безпорадності, тривожність; у поведінці спостерігаються регресія, аутизація, агресія, сексуальні ігри, мастурбація.

3. Молодший шкільний вік складності у визначенні сімейних ролей, амбівалентні почуття щодо дорослих, страх, сором, відраза, почуття неповноцінності, недовіра до світу; порушення апетиту, сну, агресивна поведінка, сексуальні дії з іншими дітьми.

4. Шкільний вік - те саме, що і для дітей молодшого шкільного віку, a також почуття втрати відчуттів, депресія; у поведінці можна помітити вплив на інших дітей для отримання статевого задоволення;

5. Підлітковий вік - сексуальні порушення, почуття відрази сорому, нерозвиненість соціальних ролей i власної позиції в сім'ї, почуття власної непотрібності; у поведінці можуть звертати на себе увагу суӥцидальні нахили, уникнення фізичної та емоційної інтимності.

Отже, аналізуючи все зазначене вище, можна зробити такі висновки. По-перше, проведений аналіз українського законодавства дає підстави стверджувати, що на сьогодні в країні не має уявлення про те, як здійснювати вплив на осіб із розладом сексуальної переваги у вигляді педофіліїз метою виправлення та перевиховання. На нашу думку, було б доцільно посилити строки покарання в статтях 155 та 156 ККУ та передбачити подальше лікуванням у психіатричному закладі або госпіталізацію до психіатричного закладу зі звичайним наглядом. По-друге, законопроєкт № 0887, у якому пропонується запровадити добровільну хімічну кастрацію, не знайшов бажаної кількості позитивних відгуків. Помилки в кваліфікації таких злочинів можна мінімізувати лише в разі максимальної оптимізації законодавчого регулювання у визначенні та характеристиці злочинів проти сексуальної свободи та недоторканності неповнолітнього. До того ж запровадження єдиного реєстру злочинців, засуджених за злочини проти статевої свободи та статевої недоторканності малолітньої особи, справді є дуже цікавою та інноваційною ідеєю, але, на жаль, цей реєстр і досі розробляється.

\section{Список використаних джерел}

1. Бугаєць Т., Ковальова О., Пашко Н. Сексуальне насильство щодо дитини: координація дій. ВГЦ «Волонтер», 2020. 39 с.

2. Дудоров О.О. Злочини проти статевої свободи та статевої недоторканності особи (основні положення кримінально-правової характеристики) : практ. порадник / МВС України, Луган. держ. ун-т внутр. справ ім. Е.О. Дідоренка. Сєвєродонецьк : РВВ ЛДУВС ім. Е.О. Дідоренка, 2018. 92 с. 
3. Вартанян Г.А, Преступления против половой неприкосновенности и половой свободы личности несовершеннолетних: судить или лечить? Вестник СПбГУ. 2016. № 16. С. 143.

4. Левенець I.В. Судова психіатрія : навчальний посібник. Тернопіль : Економічна думка, 2005. 328 с.

5. David Porter DSM-5 Category: Paraphilic Disorders. URL: https:// www.theravive.com/therapedia/pedophilic-disorder-dsm--5-302.2.

6. Кримінально-виконавчий кодекс України : Закон України від 11.07.2003. Відомості Верховної Ради України. 2020. № 3-4. Ст. 21.

7. Кримінальний кодекс України : Закон України від 5 квітня 2001 р. № 5460-VI (5460-17). URL: http://zakon1.rada.gov.ua.

8. WorlingJ.R., Curwen T., Adolescent sexual off ender recidivism: success of specialized treatment and implications for risk prediction. Child Abuse Negl. $2000 \mathrm{Jul}$. Vol. 24 (7). P. 965-982.

9. Янішевська К.Д., Савицька І.В Щодо проблем педофілії в Україні. Актуальні проблеми вітчизняної юриспруденщї. 2020. № 1. С. 131.

10. Сексуальне насильство над дітьми - біда, що ближче, ніж здається. Громадська організація «Ла Страда - Україна». URL: http://www.lastrada.org.ua/ucp_mod_ news_list_show_511.html.

11. Гутник А.Д., Дворянчиков Н.В. Социальные представления о сексуальном насилии над детьми. Психология и право. 2012. № 2. С. 6-7.

Меркулова Ю. В., Даніч М. А. Колізії в українському законодавстві щодо злочинів, скоєних проти статевої свободи та статевої недоторканості малолітньої особи

У статті аналізуються питання стосовно проблеми, пов'язаної з вибором методів примусового впливу на осіб, які скоїли злочини сексуального характеру щодо дітей згідно із законодавством України та медичними нормативами. Це питання гостро постає перед державою, адже діти сьогодні є однією 3 найбільш вразливих і незахищених категорій населення. Такі злочини, особливо ті, що набувають розголосу, підбурюють суспільство, провокують спроби самосуду. Тим паче, що саме такі злочини деморалізують наступне покоління, впливають на формування моральних цінностей. Ще однією серйозною проблемою є те, що майже немає статистики про людей із розладом сексуального збочення у формі педофілії, які ніколи не скоювали злочини проти дітей, хоча існування такої категорії, на думку багатьох авторів, не викликає сумнівів. Також майже немає жодної інформації про справжню поширеність цієї девіації.

Автори статті, аналізуючи проблему, наголошують на тому, що проведений аналіз українського законодавства дає підстави стверджувати, що на сьогодні в країні не має уявлення про те, як здійснювати вплив на осіб із розладом сексуальної переваги у вигляді педофілії з метою виправлення та перевиховання. На нашу думку, було б доцільно посилити строки покарання в статтях 155 та 156 ККУ та передбачити подальше лікування у психіатричному закладі або госпіталізацію до психіатричного закладу зі звичайним наглядом. Законопроєкт № 0887, у якому пропонується запровадити добровільну хімічну кастрацію, не знайшов бажаної кількості позитивних відгуків. Помилки в кваліфікації таких злочинів можна мінімізувати тільки в разі максимальної оптимізації законодавчого регулювання у визначенні та характеристиці злочинів проти сексуальної свободи та недоторканності неповнолітнього. До того ж запровадження єдиного реєстру злочинців, засуджених за злочини проти статевої свободи та статевої недоторканності малолітньої особи, справді є дуже цікавою та інноваційною ідеєю в Україні, але, на жаль, цей реєстр і досі розробляється.

Ключові слова: педофілія, сексуальне насильство, малолітні особи, покарання, законодавство. 
Меркулова Ю. В., Данич М. А. Коллизии в украинском законодательстве относительно преступлений, совершенных против половой свободы и неприкосновенности малолетнего лица

В статье анализируются вопросы по проблеме, связанной с выбором методов принудительного влияния на лиц, которые совершили преступления сексуального характера относительно детей, согласно законодательству Украины и медицинских нормативов. Этот вопрос остро стоит перед государством, поскольку дети сегодня являются одной из самих уязвимых и незащищенных категорий населения. Такие преступления, особенно те, которые приобретают огласку, вызывают гнев у общественности, провоцируют попытки самосуда. Тем более, именно такие преступления деморализуют следующее поколение, влияют на формирование моральных ценностей. Еще одной серьезной проблемой является то, что практически нет статистики о людях с расстройством сексуального извращения в форме педофилии, которые никогда не совершали преступлений против детей, хотя существование такой категории, по мнению многих авторов, не вызывает сомнений. Также почти нет никакой информации о реальной распространенности этой девиации.

Авторы статьи, анализируя проблему, отмечают, что проведенный анализ украинского законодательства, дает основания утверждать, что на сегодняшний день в стране нет представления о том, каким образом влиять на лица с расстройством сексуального извращения в виде педофилии с целью исправления и перевоспитания. По нашему мнению, было бы целесообразно усилить сроки наказания в статьях 155 и 156 ККУ и предусмотреть дальнейшее лечение в психиатрическом учреждении или госпитализацию в психиатрическое учреждение с обычным надзором. Ошибки в квалификации таких преступлений можно минимизировать лишь в случае максимальной оптимизации законодательного регулирования в определении характеристики преступлений против сексуальной свободы и неприкосновенности несовершеннолетнего. К тому же введение единого реестра преступников, осужденных за преступления против половой свободы и половой неприкосновенности малолетнего лица, действительно является очень интересной и инновационной идеей в Украине, но, к сожалению, данный реестр и до сих пор разрабатывается.

Ключевые слова: педофилия, сексуальное насилие, малолетние лица, наказание, законодательство.

Merkulova Yu., Danich M. Collisions in Ukrainian legislation concerning crimes against sexual freedom and sexual integrity of a minor person

The article analyzes the issues to the problem related the choice of methods of coercive influence on persons who have committed sexual crimes against children in accordance with the legislation of Ukraine and medical standards. This question is acute for the state, because children today are one of the most vulnerable and unprotected groups. Such crimes, especially those that become public, incite society, provoke attempts at self-judgment. Moreover, such crimes demoralize the next generation, influence on formation of moral values. Another serious problem is that there are virtually no statistics of people with a sexual perversion disorder in the form of pedophilia who have never committed crimes against children, although the existence of such category, according to many authors, is not in doubt. There is also almost no information about the true prevalence of this deviation. The authors of the article, analyzing the problem, emphasize that analysis of Ukrainian legislation gives grounds to claim that today the country has no idea how to influence people with sexual dysfunction in the form of pedophilia in order to correct and re-educate. In our opinion, it would be appropriate to enhance the sentence in Articles 155 and 156 of the Criminal Code of Ukraine and to provide further treatment in a psychiatric hospital or admission to a psychiatric institution with ordinary supervision. 
Enactment № 0887, which proposes to introduce voluntary chemical castration, did not find the desired number of positive reviews. Faults in the qualification of such crimes can be minimized only if the legislative regulation in the definition and characteristics of crimes against sexual freedom and inviolability of a minor is optimized. In addition, the introduction of a single register of criminals convicted of crimes against sexual freedom and sexual integrity of a minor is indeed a very interesting and innovative idea, but, unfortunately, this register is still being developed.

Key words: pedophilia, sexual violence, minors, punishment, legislation. 